\title{
A MEANINGFUL BRAIN-BASED LITERATURE LEARNING MODEL
}

\author{
ELYUSRA \\ Muhammadiyah University of Bengkulu \\ Yusra.el.261@gmail.com
}

\begin{abstract}
The objective of this research is to design a model of literary study in accordance with students and lecturers needs at the Faculty of Teacher Training and Education in Muhammadiyah University of Bengkulu. This is a research and a developmental study by using the Borg and Gall's method. It is conducted through identification of students and lecturers' needs toward the models of literature learning, literature review, model design, and validity test from the expert's judgment. The result of this research was a Meaningful Brain-Based Literature Learning Model which had been validated by two experts. This model covers the components of the plan, implementation, and evaluation.
\end{abstract}

Keywords: instructional models, instructional literature, meaningful learning, brain-based learning

Various dimensions of literary ability should have the attention in learning. Rohmat said (2012: 16 - 17) "teaching literature is interactional process to build knowledge about literature or humanities". Stanton (2012: 16 - 17) stated "the problem of literary knowledge as the ultimate goal of teaching literature is congruently a problem of conceptions, hypotheses, and aspects related to literature". Chambers \& Gregory (2006: 37) stated that the learning objectives of literature are the analysis, interpretation, and assessment. Students should engage with primary and secondary texts, create their own questions, and produce literary texts so that they are involved in critical processes. In short, the study of literature is hermeneutic, inter-textual, participate, worthy, depending on the context, and relative no limit.

From the researcher's experience while learning literature subjects at School of Education of Muhammadiyah University in Bengkulu (MUB), the researcher get the fact that the students learning outcomes are still low, both in the aspect of the process and the results. Mastering literary theory is still low; it is seen from the average test results of $42.58 \%$ (Elyusra, 2011). Students experience to enjoy the literary is very low, only a few students who read two or three novels and not all students learn the teaching material.

From the results of informal interviews with students, it is shown that teaching literature they have studied does not allow them to analyze, interpret, and assess the literary well. Students tasks from the university are not relevant yet; there is no obligation for the students to read the literature and report it. In addition, the students stated that the assessment was really based on the assessment of a final written test at the end of the semester while the students did not get any information about the assessment criteria. The lecturers stated that the students are still passive in learning. It makes the lecturers work hard to have their students be active in learning. The students do not have good test results and do not do their tasks by themselves. The explanation above is a description of learning literature problem if the assessment focuses only on the test results. Thus, the attention to the learning process and assessment becomes an important and strategic thing to realize the essence of literature learning.

Based on the above facts, it needs significant improvement. It is about how to conduct study and development model of the brain-based and meaningful literature learning. The meaningful learning focuses on linkages between new lessons and cognitive structures of students and learning purposes. The brain-based learning is the learning referring to the 
results of neuroscience study to achieve maximum learning results. The combination of these two theories can overcome the disadvantages of literary learning model so far. As one of the research steps, the disclosure of the students and lecturers requirements on literature teaching model is very important because it will be the basis for designing the model.

Prawiradilaga (2008: 33) said that "the term of model can be interpreted as a graphic display and regular or systematic working procedures containing thought of a description or explanation with the advice". Winataputra (2010: 62) stated that "model can be understood as a conceptual framework that is used as a guideline in conducting an activity". Thus, in the context of learning, "model can be interpreted as a conceptual framework and regular or systematic working procedures that contain thought of a description or explanation with the advice and it is used as a guideline in conducting lessons.

Dick, Carey, and Carey Model (2001:6-8) is one of instructional development models that are often used. He developed steps to: (1) identify the general instructional objectives, (2) do the instructional analysis, (3) to identify the students behavior and early characteristic, (4) write performance goals, (5) develop a reference test items, (6) develop instructional strategies, (7) develop and select instructional materials, (8) design and implement the formative evaluation, (9) revise instructional activities, and (10) design and implement the summative evaluation.

Meaningful learning is if the knowledge the students accepts is suitable to him, the student understands the use of science that he learned, and he is encouraged to try to practice it in his life and environment. Meaning is something memorable, useful, and really motivating to live better (Hernowo, 2004: 66 - 68). According to Wilson, learning should familiarize the students to be active, constructive, collaborative, intentional, complex, contextual, conversational, and reflective (Trianto, 2011). Ronis (2011:119) stated one of the best learning strategies appropriate to the brain work is a learning model of cooperation or collaboration (a cooperative or collaborative model for learning). It is also stated, an effective learning is to practice so that it can last a long time (Ronis, 2011: pp. xviii).

The implementation of the above meaningful learning principles is in accordance with the brain-based learning model. Jensen (2013: 16) stated that the brain-based learning model is the active involvement of practical strategies based on the principles of learning and behavior obtained from neuroscience. By using the knowledge about the brain, learning practitioners can reach more students, more often, with a smaller error rate (Jensen, 2008: 12).

Brain-based learning is best understood in three words: engagement, strategies, and principles. Engagement is the students active involvement. Strategies are aimed strategies based on principles derived from an understanding of the brain. Principles are derived or built from neuroscience (Jensen, 2011: 5-6). It is also stated that "we learn best by immersing ourselves; by jumping into the fray, then thinking how to get out of there". This is a natural tendency of the brain. However, it is emphasized that this idea does not mean to suggest the unnecessary structure (Jensen, 2008: 478 -479).

Steps of Brain Based Learning stated by Jensen are: 1) pre-exposure (giving a review to the brain about the new learning); 2) preparation (creating curiosity or pleasure similar to "setting the anticipatory conditions", but a bit further in preparing students); 3) acquisition (granting preliminary fact full of ideas, details, complexity, and meaning); 4) elaboration (processing steps that require the ability to think purely); 5) incubation and memory formation (time to break and repeat); 6) verification and testing confidence 
(confirming the learning phase); 7) celebrations and integration (celebrating phase involving emotional stages using new learning, for further confirmation and extend learning (Jensen, 2008: 57; Jensen, 2011: 233).

Characteristics of meaningful and brain-based literature learning require assessment practices that are not just a paper and pencil test. An assessment system is needed to monitor the whole process and aspects of learning associated with the formation of literature competence on the cognitive, affective, psychomotor, and metacognitive domains. The needed assessment is an assessment appropriate to the brain works. The assessment principles in accordance with the brain works are implicated in aspects of meaningful learning and brain-based learning that have been stated previously, such as cooperation, interdependence, success for all students, interactive learning, performance assessment, learning cooperation environment (Ronis, 2011: $\mathrm{x}$ ).

Both of the above learning models are combined in order to maximize the principles and procedures of existing literature learning. The application of meaningful and brainbased literature learning models in School of Education UMB is believed to overcome the above problems. This is due to the relevant model to the nature of literature learning and it can optimize ideal principles and procedures of literature learning. This combination is conducted by referring to the opinions that the teaching model is not entirely able to meet the students' needs (Joyce, Weil, and Calhoun 2009: xxxiii). Rose and Nicholl expressed that "a lot of windows toward the same room means that the subjects can be approached and studied from various perspectives" (2002: 63). Slameto said "each approach is suitable for certain lessons and units (1995: 113).

Until now, the researchers have not found the results of the study and the development of literary learning model using a combination of meaningful learning theory and the brain-based learning theory. Several previous relevant studies are as follows.

Zaqiah's study (2013), "The Implementation of Brain Based Learning to Enhance Students' Critical Thinking Skills, a Quasi-Experimental Study", S3 thesis, Education University of Indonesia (UPI). The findings of the study were the brain-based learning can improve students' critical thinking skills at different rank schools as students behave positively towards the brain-based learning. Setiawati's study in 2006, a thesis entitled "Efforts to Improve Short Story Writing Ability through A Brain Based Learning Approach (Classroom Action Research on Grade 9 of X-F Senior High School 5 Bandung academic year 2009/2010)". The research results prove that students' ability has been improved in writing short stories. The conclusion of the research is the application of brain-based learning approach in an effort to improve the ability of writing short stories showing a significant success (2013). Misbahudholam's. (2012). entitled "Effects of Brain-Based Learning on the High-Level Thinking Skills of Students in Class XI-IPS MA A.W. Waljamaah, Ambuten Sumenep. The result of this quasi experiment research stated that the high level thinking skills in geography by using the brain based learning have an average value higher than the skills without using the brain-based learning. Indra and Yuda's, et. Al. (2014). "Effects of Brain Based Learning Model on Mathematics Learning Outcomes o Students at Class V of Elementary School in the Village of Sinabun". This type of quasi-experimental study showed that the application of brain based learning model effects positively on students' mathematics learning outcomes compared with conventional models.

A relevant study on the meaningful learning that researchers pointed out is the action research conducted by Tomasouw titled: Using Advance Organizer to Improve Students Reading Comprehension of German Texts in Grade XII IB SMAN 1 Ambon. The study 
stated that the Advance Organizer technique gave results of the better understanding in German language text (Tomasouw, 2009: 74). Advance Organizer is a teaching technique based on the theory of Ausubel's meaningful learning that researchers also used in the study and development.

Some information from the data above is that the brain based learning has been applied to a wide range of subjects and various levels of education, by bringing in better learning outcomes and achieving high levels of learning outcomes. Advance Organizer as a meaningful teaching technique by Ausubel has been applied and it can enhance students' understanding of the German language text. However, the study and development of literary learning model by combining both theories above are undiscovered.

Based on the above explanation in this paper, the problem of the study is how the literary learning model that fits the needs of students and lecturers is applied in School of Education MUB? The study objective is to design a literary learning model in accordance with the needs of the lecturers and students to be applied in School of Education MUB.

\section{METHOD}

The study method used to achieve the purpose of the above study is through research and development. Research and development in the educational field, proposed by Borg \& Gall, is as the process used to develop and validate the educational product. The main measures of $\mathrm{R} \& \mathrm{D}$ proposed by Borg and Gall are: 1) Research and Information Collecting, 2) Planning, 3) Develop Preliminary Firm of Product, 4) Field Testing and Product Revision, 5) Final Product Revision, 6) Dissemination and Implementation (1989: 626). In accordance with the objectives of this study, the undertaken measures are the first step to the fifth. In practice, the procedure of the research and development is combined with a model of instructional development proposed by Dick and Carey as mentioned above.

The research and development are carried out in the Indonesian Language and Literature Study Program, School of Education UMB September 2013, involving three teachers and 90 students. The phase of experts' study was carried out by two experts in the field of research and development in the Indonesian language and literature education. The sampling technique was done by using purposive and simple random sampling technique.

Data was collected by interview and questionnaire techniques. The instrument used was the guides of interview and questionnaires developed with the stages and measures suggested by Djaali and Muljono (2008: 60-61). The measures of instruments preparation and development are: 1) formulating a variable construct, 2) developing the dimensions and indicators of variables; 3) creating grids, 4) determining the amount or parameters, 5) writing grains instruments, 6) validating theoretical, 7) implementing the revised instrument; 8) testing instrument that is an internal validation test including validation of the contents and construction; 9) carrying out the multiplication of instruments to be used. Guided by the advice from Bogdan and Biglen (1982: 42), Muhadjir (1998: 30), and Milles and Huberman (1992: 73 - 106), the measures of data analysis are: 1) examining the data, which checks all data such as factual notes having been collected in terms of compliance with the expected data and the need to answer the problem; 2) organizing data, which classifies data according to the research questions; 3) making or writing a descriptivereflective note; 4) describing each group of data to answer the research questions that have been set. 


\section{RESULTS}

The following data is the analysis result of questionnaire identifying respondents' needs as students and lecturers. The results of identifying needs are considered in preparing the learning model.

\section{1) The students' needs to literature teaching model}

The students' needs to instructional model are seen from nine aspects. The literary learning models that students need are: 1) to achieve the learning objectives in the cognitive, affective, psychomotor, and metacognitive aspects; 2) learning materials including the concept of literature appreciation, literature study, kinds of literary theory and its application, theory of literature performance, theory of literature creation; 3) the type of materials needed such as facts, concepts, principles, and procedures in the literature; 4) to organize the learning conducted by paying close attention to the science structure and to the adjustment of the literary characteristics, the students' characteristics, and the students' prior knowledge; 5) learning environment with proportional facilitation and challenges, the familiarity between lecturers and students, and learning interspersed with humor; 6) learning activities including face-to-face lectures, independent activities, writing guidance class, and integration of metacognitive learning; 7) learning management implemented by informing learning procedures clearly, students' learning progress noted orderly by lecturer and accessed by students, as well as using various learning methods; 8) sources, media, and adequate learning materials that are varied and affordable; 9) learning evaluation including the process and results, written tests, practical tests, clear criteria, and informed to the students, achieved collaboratively, with the challenging standards, and meaningful feedback.

\section{2) The lecturers' needs to literature teaching model}

Lecturers' needs to literature teaching model to be applied in School of Education UMB in this study are seen from eight aspects. Based on the results of questionnaire analysis, literature learning models needed by lecturers are: 1) to set a variety of literary learning objectives to be achieved and described in detail; 2) to describe the material, so that the learning can be conducted well and can facilitate the preparation of learning tools; 3 ) to organize the learning by considering the science structure, literature and students' characteristics; 4) to provide an overview of the learning environment; 5) to design a learning activity with its facilities for students, high student learning activities, and appeal learning activities; 6) to determine the strategy and a clear implementation schedule, the note model of student learning progress; 7) to provide sources, tools, and various learning media; 8) to do evaluation with regard to aspects of cognitive, affective, psychomotor, and metacognitive learning that has open characteristic, authentic assessment, and the examples of evaluation instruments that can be used by lecturers, especially for the assessment of attitudes and psychomotor aspects.

\section{2) The Design of meaningful brain based literature learning model}

Based on the data of the students' and lecturers' needs to literature learning model and the results of a literature review, it can be stated that literary learning models in accordance with the students' and lecturers' needs is the model of the meaningful brain based literature learning (MPS- BBO). It is to validate the prepared draft model through the expert study (expert judgment). The results of the validation tests through the expert study are obtained by using the assessment rubric with the score scale of $1-5$. It means number $1=$ very poor, $2=$ less, $3=$ moderate, $4=$ good, and $5=$ very good. The maximum score is 80 and the minimum score is 16 . Based on the results of the two experts' assessments, the meaningful brain based literature learning models gain the score: 
Table 1. Experts' Assessment on the Preliminary Model

\begin{tabular}{|c|c|c|}
\hline No. & MPS - BBO Aspects & Score \\
\hline 1 & $\begin{array}{l}\text { Completeness of model } \\
\text { complements }\end{array}$ & 4 (good) \\
\hline 2 & $\begin{array}{l}\text { Suitability of the model with the } \\
\text { concepts, principles, and } \\
\text { procedures of meaningful } \\
\text { learning and brain- based } \\
\text { learning }\end{array}$ & $\begin{array}{l}3.83 \\
\text { (Enough) }\end{array}$ \\
\hline 3 & $\begin{array}{l}\text { Practicality of models to be } \\
\text { implemented in learning }\end{array}$ & $\begin{array}{l}4.125 \\
\text { (Good) }\end{array}$ \\
\hline 4 & $\begin{array}{l}\text { Understanding of Serving } \\
\text { Model }\end{array}$ & 4.33 (Good) \\
\hline 5 & $\begin{array}{l}\text { Accuracy of model focused on } \\
\text { the achievement of literature } \\
\text { learning goals in FKIP literature }\end{array}$ & $\begin{array}{l}3.5 \\
\text { (Enough) }\end{array}$ \\
\hline \multicolumn{2}{|c|}{$\begin{array}{c}\text { The average scores given by the two } \\
\text { experts }\end{array}$} & $\begin{array}{l}3.97 \\
\text { (Enough) }\end{array}$ \\
\hline
\end{tabular}

Based on the input or advice from experts, improvements or revision of the model are carried out. The revision model (Draft 2) is based on the results of the experts' study as presented in the following chart. 


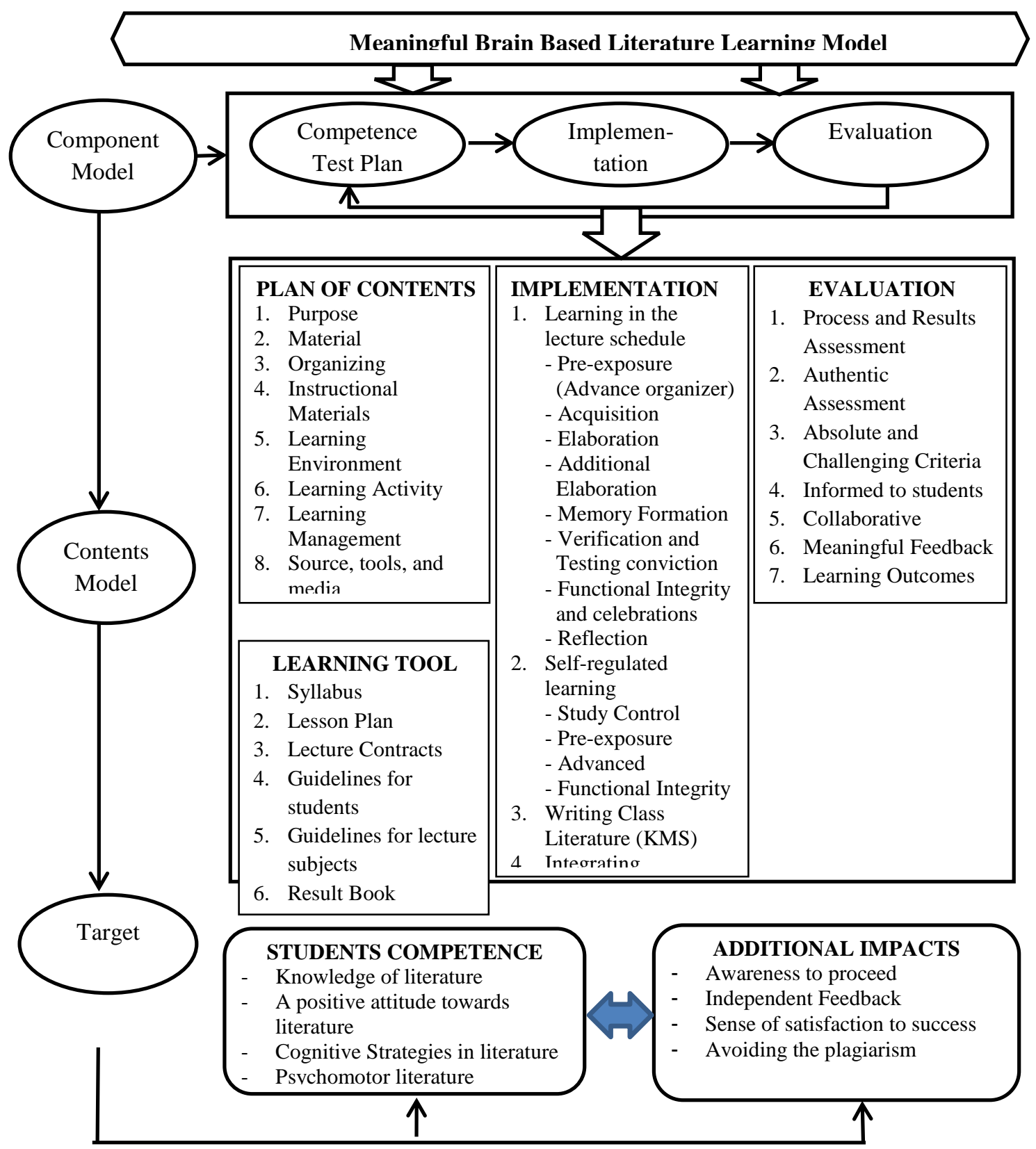

Chart: 1 Design Model of Meaningful Brain Based Literature Learning 
Based on the above learning model, the syntaxes of meaningful brain based literature learning are in the following chart:

\begin{tabular}{|c|c|c|}
\hline \multicolumn{3}{|c|}{$\begin{array}{r}\text { Pre-exposure (-A.1) } \\
\text { (It is conducted when lecturers deliver topics of the }\end{array}$} \\
\hline \multicolumn{3}{|c|}{25} \\
\hline \multicolumn{3}{|c|}{$\begin{array}{l}\text { Pre-exposure (-A. 2) } \\
\text { (It is conducted on independent activities, when students read the material delivered } \\
\text { before it is discussed in the lecture schedule) }\end{array}$} \\
\hline \multicolumn{3}{|c|}{ r } \\
\hline \multicolumn{3}{|c|}{ Face to Face Learning Stages on the Class Schedule } \\
\hline First Stage & \multicolumn{2}{|c|}{$\begin{array}{l}\square \text { Pre-Exposure (A) / Preparation } \\
\square \text { Objectives / purposes of learning } \\
\square \text { Advance organizer } \\
\square \text { Reasons / benefits of learning } \\
\square \text { Management of learning }\end{array}$} \\
\hline $\begin{array}{l}\text { Main stage } \\
\text { (integrating affective and } \\
\text { metacognitive learnings) }\end{array}$ & \multicolumn{2}{|c|}{$\begin{array}{l}\square \text { Acquisition } \\
\square \text { Elaboration } \\
\square \text { Elaboration Supplement } \\
\text { (A deeper understanding and feedback) } \\
\square \text { Memory formation }\end{array}$} \\
\hline Final Stage & \multicolumn{2}{|c|}{$\begin{array}{l}\square \text { Reflection } \\
\square \text { Celebrations and functional integrity } \\
\square \text { Management of learning }\end{array}$} \\
\hline \multicolumn{3}{|c|}{2} \\
\hline $\begin{array}{l}\text { Mentoring Scientific } \\
\text { and Creative Writings }\end{array}$ & $\begin{array}{l}\text { WRITING LITERATURE } \\
\text { CLASS }\end{array}$ & $\begin{array}{l}\text { face to face } \\
\text { at the end of the study }\end{array}$ \\
\hline $\begin{array}{l}\text { Memory Formation } \\
(\text { Continued })\end{array}$ & SELF-STUDY & Pre-Exposure \\
\hline
\end{tabular}

Chart 2. The Syntaxes of Meaningful Brain-Based Literature Learning

\section{DISCUSSION}

Based on the study results that have been described above, the discussion of the findings is as following here.

\section{1) The students' and lecturers' needs to master the literary competence}

Both students and teachers require achieving learning objectives in various domains/literature teaching purposes, such as cognitive, affective, psychomotor, and metacognitive at various levels. This is an ideal goal of teaching literature as stated (Stanton, 2012: 16- 17) that "Congruently, the literary knowledge as the ultimate goal of teaching literature is the issue of conceptions, hypotheses, and aspects related to literature". Chambers \& Gregory also expressed that the learning objectives of literature are the analysis, interpretation, and assessment. Literary studies are hermeneutic, inter-textual, participatory, full of value, depending on the context, and relatively no limit (2006: 37). In connection with the objectives of affective domain, it is also stated that the learning literature has many specific disciplines and cognitive purposes, but the most common and basic purposes, objectives of the development are to develop the society and emotionally 
make more advanced (Chambers \& Gregory, 2006: 37). The cognitive and affective objectives are like two sides of a coin, which can be closely linked and mutually supportive. Suciati (1997: 2- 50) stated that "In the learning process, cognitive and affective aspects are certainly two sides of a coin that is necessary.

The purpose of the psychomotor is also an ideal purpose to be realized because it is very relevant to the nature of literature as a creative art works that are not only enjoyed mentally, but also through performance or performances involving physical processing. The physical activity is very necessary for the maximum cognitive achievement. Jensen stated that physical movements are: 1) improving the circulation, so the nerves get more oxygen and nutrients; 2) stimulating the production of nerves, a hormone that increases brain function; 3) improving mood; and 5) increasing new cells in the brain" (2011: 50). With regard to the students' needs in the ability of cognitive strategies, in line with the view from Depoter, et al. It was stated that the absolute ability students have to possess is to achieve maximum learning results. Depoter, et al. (2000: 164) called it as a learning skill to learn. He said that all lessons will be faster and more effective if the students master the skill. The five essential skills are concentration focused, how to record, organization and preparation of the test, speed reading, and memorizing techniques. The importance of cognitive strategies can be seen in the following description:

...Students use cognitive strategies to read an article in the scientific magazine... they learn from the article probably just the facts, formulas, or the application of the theory. However, to select the information they have read gives the code to the information they have had in their minds and rediscover the information for other purposes. It is a cognitive strategy" (Pannen, 1997: 3-12).

Based on the above explanation, it is an appropriate policy to assign different learning objectives and make it happen in learning literature.

\section{2) The students' and lecturers' needs to the scope of learning materials}

In general, students and lecturers expressed that they really need a wide range of coverage relevant materials and use them to reach the learning objectives. There is a tendency for students to declare that they need materials that have been familiar and unfamiliar or new for them. However, based on the further information, it is found the fact that the student has not mastered the material yet.

Based on data of students' needs above, in conducting the lecture contract is necessary for the lecturer to provide information about the development of literary nowadays. In addition, students should also have the understanding that the material position in learning is as the objectives to be achieved. Limiting the learning material is just like limiting the objectives to be achieved. Limited purposes mean that literature learning conducted is inconsistent or irrelevant to the development of literature and humanities.

\section{3) The students' and lecturers' needs to the material types}

The questionnaire results showed that students need all kinds of materials, which include: facts, concepts or definitions, principles, and procedures. As the structure of the literature study is a dual structure, which combines the orientation structure and the supporting structure, it requires the various types of material in the learning model. The higher the level of competence is achieved, the more various the types of materials will be needed. For example, students who study Literature Criticism will be able to write a paper of literary criticism with a structural approach when they master the material of literary 
genre theory criticized, control the nature of literary criticism, and master the principles and procedures of structural criticism.

\section{4) The students' and lecturers' needs to the model of learning organization}

In general, both students and lecturers need a learning organization in accordance with the science structure. This finding is in line with the views Ausubel (2011: 282) expressed that he believes there are parallels between the way the subjects are treated and the way people process information in their minds (cognitive structures). He argued that each academic discipline has a concept structure (and/or a design) which is managed hierarchically. In addition, students also need the learning organization that is not linear. The students' needs can be understood if it is associated with the characteristics of students who already have experience of studying literature. For example, in learning how to create literary texts, students can start at the beginning of the semester although the materials of writing literary have not been discussed. Doing these tasks can be conducted because the students have been studying the structure of literary, have had the experience of reading literature, has read the creative process of creating someone's literary, even have written a literary at their previous educations. This fact can be understood because it is in line with the phenomenon of the creative process that is performed by the author with his phenomenal work. For example, Andrea Hirata with his Laskar Pelangi, Ahmad Fuadi with his Negeri Lima Menara, Hanum Salsabila Rais and Rangga Almahera with 99 Cahaya di Langit Eropa, and Habiburrahman el Shirazy with his Ayat-ayat Cinta. Although it is known that they have not had any formal educations in language and literature.

Winkel (2004: 411)stated that instructional steps generally follow the sequence of phases in the learning process:

"Even certain instructional steps may be skipped all because students are able to set their own external conditions, for example, students have motivated themselves by reading the relevant literatures (self-instructional)"

Lecturers tend to organize the learning by following the linear studying phases. Although it is naturally in line with the workings of the brain, learning can run in nonlinear ways.

\section{5) The students' and lecturers' needs to the model of learning environment}

In general, the environment of literature learning with characteristics of humor, facilitation, challenges, and familiarity is a learning model the students really require. From the lecturers' side, the teaching model with the environment as the students require above is a supporting factor that facilitates the learning process and raises students' motivation in order to achieve the learning objectives in good quality, and also to enhance the prestige of the institution.

The students' and lecturers' need to the learning environment is in line with the new view of learning adopted nowadays. One new approach of how to learn Meier (2002: 29) stated that characterized by:

"The students' full involvement, pure collaboration, variation and uniformity in the

learning methods, internal motivation (and not merely external). Their excitement and pleasure in learning, and learning integration into the entire life of the organization".

\section{6) The students' and lecturers' needs to the model of learning activities}

Both students and teachers expressed their needs to the three forms of learning, they are face to face learning on the lecture schedule, independent activities, the integration of affective and metacognitive learning aspects, and "Writing Literature Class". The lecturer 
stated that the learning activities are very effective and efficient to achieve learning outcomes. Three lecturers are ready to perform their role in the learning activities above. To ensure the implementation of learning activities above, it must be supported by good management of learning, such as setting or scheduling that students agreed through lecture contract, applying a flexible schedule, and implementing the schedule with the adjustments that benefit both students and lecturers.

\section{7) The students' and lecturers' needs to the model of learning management}

Students need a learning management model with the following characteristics: 1) Lecturers inform the instructional procedures that will be used and the tasks students have to do; 2) Lecturers write students' learning outcomes orderly; 3) the learning progress that has been achieved can be seen by students; 4) Lecturers inform learning materials and students' assignments at the beginning of the semester to let students have the freedom in learning; and 5) Lecturers use various teaching methods so that students can learn based on their types of learning.

The students' and lecturers' need above can be fulfilled by the development of learning tools. The learning tools that maximize the learning management are lecture syllabus, lesson plans, manuscript of lecture contract, guidebooks for lecturers and students, value reports, and other learning tools in the classroom that are prepared or developed well.

\section{8) The students' and lecturers' needs to the teaching model with source, tool, and material aspects}

Students and lecturers need a learning model with various sources, tools, and learning materials. The learning paradigm nowadays demands a variety of learning resources because recently lecturers can no longer act as the only learning source. Besides it is caused by both the rapid development of science and the development of learning sources that can be used by lecturers and students. The learning materials that are growing cannot be presented by lecturers anymore. Besides the achieved results are not maximal, the presentation will also be constrained by time and effort factors. Commercialized learning resources such as books, magazines, newspapers, scientific journals, lecturers' researches, students' thesis can be used as a learning resource. In addition, other learning resources such as electronic media learning resources can also be used.

Learning tools have already been more various. It demands teachers' ability to provide the tools. Learning materials also can match students' characteristics, lecturers' capabilities, and students' abilities.

\section{9) The students' and lecturers' needs to the model of learning evaluation}

Students desperately need a model of literature learning evaluation with the same characteristics and the complex principles. Based on the assessment characteristics that students need, it means that lecturers should have the competence to carry out and implement or do it in the literature teaching.

Both students and lecturers need a model of learning evaluation with cognitive, psychomotor, affective, and metacognitive aspects. On the other hand, there are still lecturers who have not implemented assessments with characteristics students need, have not developed evaluation instruments, and even there are lecturers who expect to have the sample of evaluation instruments, especially for the assessment of attitudes and psychomotor aspects.

Admitting the limitations of this study, researchers can say that the model of meaningful brain-based literature learning described above has not been a final model and 
the test results of the effectiveness have not been stated. Therefore, it still needs more information to all who will implement the model.

\section{CONCLUSION}

Based on the study results and discussion above, it can be stated that students of Indonesian Language and Literature Education in School of Education MUB require a literary learning model that is capable to guide them to have competence in the literature field with various aspects, such as cognitive, affective, psychomotor, metacognitive aspects. Students need to achieve all levels in every aspect. Therefore, students need various learning and teaching materials. Other findings are that students require more facilitation from lecturers and also clear and open learning systems.

From the lecturers' side, it is found that basically lecturers require a teaching model with the same learning objectives that students need. Lecturers require a literature teaching model coming with learning tools that can assist them in carrying out the teaching process. The model of meaningful brain-based literature learning (MPS-BBO) is a design of learning model based on students and lecturers need in School of Education MUB.

\section{BIBLIOGRAPHY}

Bogdan, R. and Biklen, S. K. (1982). Qualitative Research for Educational and Introduction to Theory and Methods. Boston: Allyn and Bacon Mass.

DePorter, Bobbi, et al. (2000). Quantum Teaching. Ary Nilandari's translation. Bandung: Mizan Main Media.

Dick, Walter, Carey, Lou and Carey, James O. (2001). The Systematic Design of Instruction. Sixth Edition. Boston: Pearson.

Djaali and Muljono, Pudji. (2008). Pengukuran dalam Bidang Pendidikan. Jakarta: Grasindo.

Elyusra. (2011). The Attendance List and Final Examination Scores, Indonesian Language and Literature Education Department, Academic Year 2010/2011, Subject of Prose Fiction Studies and Appreciation.

Hernowo. (2004). Bu Slim \& Pak Bil Membincangkan Pendidikan di Masa Depan. Bandung: Mizan Learning Center.

Jensen, Eric. (2008). Brain-Based Learning, Pembelajaran Berbasis Kemampuan Otak: Cara Baru dalam Pengajaran dan Pelatihan. Yogyakarta: Pustaka Pelajar.

(2011). Pembelajaran Berbasis Otak, Paradigma Pengajaran Baru. Benjamin Molan's Translation. Jakarta: PT index.

Joyce, Bruce, Weil, Masha, and Calhoun, Emily. (2011). Models of Teaching Acmad Fawaid's and Atailla Mirza's Translation. Yogyakarta: Pustaka Pelajar.

(2009). Model of Teaching, Model-model Pengajaran. Acmad Fawaid's and Atailla Mirza's Translation. Yogyakarta: Pustaka Pelajar. 
Meier, Dave. (2002). The Accelerated Learning Hand Book: Panduan Kreatif dan Efektif Merancang Program Pendidikan dan Pelatihan. Rahmaini Astuti's Translation. Bandung: Kaifa.

Miles, Matthew B. and Huberman, A. Michael. 1992. Analisis Data Kualitatif. Tjetjep Rohendi Rohidi's Translation. Jakarta: UI Press.

Misbahudholam, Muhammad. (2012). "Pengaruh Pembelajaran Berbasis Kemampuan Otak terhadap Kemampuan Berpikir Tingkat Tinggi Siswa Kelas XI-IPS MA Ahlusunnah Waljamaah Ambuten Sumenep, Tesis. http://karyailmiah.um.ac.id/index.php/disertasi/article/view /23220 (accessed on December $1^{\text {st }}$, 2014)

Muhadjir, Noeng. (1998). Metodologi Penelitian Kualitatif. Yogyakarta: Rakesarasin.

Pannen, Paulina. (1997). "Strategi Kognitif”, dalam Mengajar di Perguruan Tinggi. Jakarta: Depdikbud.

Prawiradilaga, Dewi Salma. (2008). Prinsip Desain Pembelajaran (Instructional Design Principles). Jakarta: Kencana.

Rizekia, Rinda. (2011). "Peningkatan Kemampuan Apresiasi Cerita Pendek dengan Menerapkan Pendekatan Pembelajaran Berbasis Kemampuan Otak (Brain Based Learning) (Penelitian Tindakan Kelas terhadap Siswa Kelas XI SMA Negeri 19 Bandung Tahun Ajaran 2010/2011)". http://repository.upi.edu/ operator/upload/s_ind_0706000_chapter1.pdf (Accessed on June $7^{\text {th }}, 2013$ ).

Ronis, Diane. (2011). Brain-Compatible Assessment: Asesmen Sesuai Cara Kerja Otak. Hartati Widiastuti's Translation. Jakarta: Index.

Rose, Colin and Nicholl, Malcolm J. (2002). Accelerated Learning for the $21^{\text {st }}$ Century. Dedy Ahimsa's Translation. Bandung: Nuansa.

Rudi, Rita Inderawati. (2008). Paradigma Baru Pengajaran Apresiasi Sastra Indonesia pada Kongres IX Bahasa Indonesia. Jakarta: Pusat Bahasa.

Sagala, Syaiful. (2010). Supervisi Pembelajaran dalam Profesi Pendidikan. Bandung: Alfabeta.

Slameto. (1995). Belajar dan Faktor-Faktor yang Mempengaruhinya. Jakarta: Rineka Reserved.

Suciati. (1997). “Taksonomi Tujuan Instruksional” dalam Mengajar di Perguruan Tinggi. Jakarta: Depdikbud. 
Tomasouw, Jolanda. (2013). Using Advance Organizer to Improve Students Reading Comprehension of German Texts in Grade XII IB SMAN 1 Ambon. http://sastra.um.ac.id/wp-content/uploads/2012/01/6.jolandaformat.docx.pdf

Trianto, Agus. (2011). “Membaca Sastra untuk Mencerdaskan, Berbasis Pembelajaran Bermakna (Meaningful Learning). Papers on Semirata, Medan.

Winkel, W. S. 2007. Psikologi Pengajaran. Yogyakarta: Media Abadi.

Yuda, Dp. Gst. Pt and Indra, et al. (2014). "Pengaruh Model Pembelajaran Berbasis-Otak (Brain-Based Learning) terhadap Hasil Belajar Matematika Siswa Kelas V SD Negeri di Desa Sinabun”. http:download.portalgaruda.org/article.php?article=105496\&val=1342.

Zaqiah, Qiqi Yuliati. (2014). "Implementasi Pembelajaran Berbasis Kemampuan Otak (Brain Based Learning) untuk Meningkatkan Kemampuan Berpikir Kritis Siswa, suatu Studi Kuasi Eksperimen pada Siswa Sekolah dasar di Kota Bandung", thesis, S3. Universitas Pendidikan Indonesia. http://repositori. upi.edu/id/eprint/2511 (Accessed on December $10^{\text {th }}$ ). 